\title{
Release of Arachidonate from Membrane Phospholipids in Cultured Neonatal Rat Myocardial Cells during Adenosine Triphosphate Depletion

\author{
Correlation with the Progression of Cell Injury
}

Kenneth R. Chien, Anjan Sen, Rolland Reynolds, Anthony Chang, Youngmoo Kim, Michael D. Gunn, L. Maximilian Buja, and James $\mathbf{T}$. Willerson

Departments of Internal Medicine (Cardiology Division) and Pathology, University of Texas Health Science Center, Dallas, Texas 75235

\begin{abstract}
The present study utilized a cultured myocardial cell model to evaluate the relationship between the release of arachidonate from membrane phospholipids, and the progression of cell injury during ATP depletion. High-energy phosphate depletion was induced by incubating cultured neonatal rat myocardial cells with various combinations of metabolic inhibitors (deoxyglucose, oligomycin, cyanide, and iodoacetate). Phospholipid degradation was assessed by the release of radiolabeled arachidonate from membrane phospholipids. In this model, the current study demonstrates that $(a)$ cultured myocardial cells display a time-dependent progression of cell injury during ATP depletion; (b) the morphologic patterns of mild and severe cell injury in the cultured cells are similar to those found in intact ischemic canine myocardial models; (c) cultured myocardial cells release arachidonate from membrane phospholipids during ATP depletion; and $(d)$ using two separate combinations of metabolic inhibitors, there is a correlation between the release of arachidonate, the development of severe cellular and sarcolemmal damage, the release of creatine kinase into the extracellular medium, and the loss of the ability of the myocardial cells to regenerate ATP when the metabolic inhibitors are removed. Thus, the present results suggest that during ATP depletion, in cultured neonatal rat myocardial cells, the release of arachidonate from myocardial membrane phospholipids is linked to the development of membrane defects and the associated loss of cell viability.
\end{abstract}

\section{Introduction}

Recent studies have suggested that alterations in sarcolemmal membrane structure and function are causally related to the development of irreversible injury during myocardial ischemia. In intact ischemic heart models, previous studies have demonstrated the presence of sarcolemmal membrane defects by electron microscopy, which correlated with the time course of the onset of irreversible injury and the accumulation of tissue calcium $(1,2)$. Previous studies in a perfused rabbit septal model related the decreases in myocardial contractile performance during ischemia with the development of increased sarcolemmal membrane cation permeability (3). Acute myo-

Address reprint requests to Dr. Chien.

Received for publication 8 May 1984 and in revised form 11 January 1985.

J. Clin. Invest.

(C) The American Society for Clinical Investigation, Inc.

$0021-9738 / 85 / 06 / 1770 / 11 \$ 1.00$

Volume 75 , June $1985,1770-1780$ cardial infarction in man is characterized by leakage of cytosolic enzymes across the sarcolemmal membrane into the vascular space (4). In addition, the accumulation of ${ }^{99} \mathrm{~m}$ technetium pyrophosphate, a probe for sarcolemmal membrane calcium permeability defects $(5,6)$, has been demonstrated to be a sensitive marker of myocardial cell injury in clinical and animal studies.

Although it is becoming increasingly clear that alterations in sarcolemmal membrane structure and function may be involved in the development of irreversible cell injury (7), the biochemical basis responsible for these membrane changes is unknown. However, recent studies in an ischemic liver model suggested that the degradation of membrane phospholipids may be causally related to the loss of cell viability during ischemia $(7,8)$. In this model, the degradation of membrane phospholipid was related temporally to the development of a membrane calcium permeability defect, a severalfold increase in tissue calcium content, and the development of irreversible damage in ischemically injured cells (8). Pharmacologic inhibition of the phospholipid degradation by pretreatment with chlorpromazine resulted in protection against the alterations in calcium homeostasis and the development of irreversible cell injury (9).

Recently, there have been several reports that arachidonic acid, a fatty acid normally present entirely in membrane phospholipid, accumulates in nonphospholipid species during myocardial ischemia (10-14). In the present study, we utilized a cultured myocardial cell model to examine the relationship between phospholipid degradation and the progression of cell injury associated with a reduction in tissue high-energy phosphate concentrations produced by different metabolic inhibitors (deoxyglucose, oligomycin, cyanide, and iodoacetate). Phospholipid degradation was assessed by the release of radiolabeled arachidonate from membrane phospholipids. The hypotheses tested in these experiments were that the accumulation of free arachidonate is $(a)$ an early indicator of membrane phospholipid degradation and $(b)$ indicative of the development of severe, and possibly, irreversible cellular injury.

\section{Methods}

Materials. $1-\left[{ }^{14} \mathrm{C}\right]$ palmitic acid $(56 \mathrm{mCi} / \mathrm{mmol})$ and $(5,6,8,9,11,12$, $14,15)\left[{ }^{3} \mathrm{H}\right]$ arachidonic acid $(87.4 \mathrm{Ci} / \mathrm{mmol})$ were obtained from New England Nuclear, Boston, MA. All solvents were high-pressure liquid chromatography grade (J. T. Baker Chemical Co., Phillipsburg, NJ). Fatty acid standards were obtained from Nu-Chek Corp., Elysian, MN, and dibromoacetophenone and dicyclohexyl-18-crown ether were obtained from Applied Sciences Laboratories, Waltham, MA. Creatine kinase assay kits were obtained from Diagnostic Systems Laboratories, Inc., Houston, TX.

Cell culture. Neonatal rat myocardial cells were cultured by a 
modification of the method of Harary and Farley (15). Whole hearts were isolated from 2-3-d-old rats and minced in a balanced salt solution containing $\mathrm{Mg} \mathrm{SO}_{4} 7 \mathrm{H}_{2} \mathrm{O}(0.2 \mathrm{~g} /$ liter $), \mathrm{NaCl}(6.8 \mathrm{~g}$ /liter $), \mathrm{KCl}$ $(0.4 \mathrm{~g} /$ liter $), \mathrm{NaH}_{2} \mathrm{PO}_{4} \mathrm{H}_{2} \mathrm{O}(1.5 \mathrm{~g} /$ /iter $)$, glucose $(1 \mathrm{~g} /$ liter $)$, and Hepes $(4.76 \mathrm{~g} /$ liter $)$ at $\mathrm{pH}$ 7.5. The myocardial cells were dispersed by the addition of a balanced salt solution containing pancreatin (Gibco Laboratories, Lawrence, MA) and $0.03 \%$ collagenase type II (Worthington Biochemical Corp., Freehold, NJ) and stirred at $37^{\circ} \mathrm{C}$. The supernatant was removed and discarded. The cells were incubated with fresh pancreatin-collagenase for $20 \mathrm{~min}$ at $37^{\circ} \mathrm{C}$. The supernatant was removed and centrifuged in a table-top centrifuge for $4 \mathrm{~min}$ at 1,400 rpm. The cells were resuspended in $2 \mathrm{ml}$ of newborn calf serum (Gibco Laboratories) and kept at $37^{\circ} \mathrm{C}$. These steps were repeated a total of four times. The cell suspensions from each digestion were combined and centrifuged at 2,100 rpm for $6 \mathrm{~min}$. The cells were resuspended in minimal essential medium $\left(1.8 \mathrm{mM} \mathrm{Ca}^{++}\right)$supplemented with $10 \%$ horse serum, $5 \%$ fetal calf serum, and $1 \%$ antibiotics (penicillin 10,000 $\mathrm{U} / \mathrm{ml}$, streptomycin $10,000 \mu \mathrm{g} / \mathrm{ml}$ ). The cell suspensions were plated for $3 \mathrm{~h}$ and the unattached cells were removed and replated on either 35- or $60-\mathrm{mm}$ cell dishes. Using these techniques, the percentage of beating myocardial cells exceeded $85 \%$ in each preparation. The cells reached confluency after $72 \mathrm{~h}$ and the incubation medium was replaced with fresh medium containing $\left[{ }^{3} \mathrm{H}\right]$ arachidonate $(3 \mu \mathrm{Ci} / 50 \mathrm{ml})$ and $\left[{ }^{14} \mathrm{C}\right]$ palmitate $(3 \mu \mathrm{Ci} / 50 \mathrm{ml})$ added in a minimal volume of ethanol. After a 24-h labeling period, the radioactive medium was removed and the cells were incubated with medium containing various concentrations of metabolic inhibitors. To induce the depletion of ATP (16), the myocardial cells were incubated with the following inhibitors (concentrations used in most experiments): $(a)$ deoxyglucose (20-30 $\mathrm{mM}),(b)$ cyanide $\left(1 \times 10^{-3} \mathrm{M}\right),(c)$ deoxyglucose $(20-30 \mathrm{mM})$, and cyanide $\left(1 \times 10^{-3} \mathrm{M}\right),(d)$ oligomycin $(0.5 \mu \mathrm{g} / \mathrm{ml}),(e)$ deoxyglucose $(20-30 \mathrm{mM})$ and oligomycin $(0.5 \mu \mathrm{g} / \mathrm{ml})$, and $(f)$ iodoacetate $(0.3$ $\left.\times 10^{-4} \mathrm{M}\right)$. In some experiments, varying concentrations of the inhibitors were employed. After various time periods of exposure to the inhibitors, the myocardial cells and extracellular medium were used for biochemical and electron microscopic analyses. In some experiments, cell dishes containing an increased proportion of nonmyocardial to myocardial cells were obtained by shortening the differential plating period to allow subsequent comparisons with data obtained from myocyte cultures. All of the various experiments were performed in triplicate groups of cell cultures with good agreement.

Lipid analyses. Aliquots of the medium and cells were extracted for lipid analysis by the method of Bligh and Dyer (17). To separate the neutral lipid and free fatty acids, aliquots of the lipid extracts were spotted on silica gel $G$ thin-layer chromatography plates and developed with a solvent system of hexane/diethyl ether/acetic acid (80:20:1.2). The various phospholipid species were separated by thin-layer chromatography utilizing a solvent system of chloroform/methanol/acetic acid/water (75:45:10:6). The lipid spots were visualized under ultraviolet light by spraying with $0.02 \%$ dichlorofluoroscein, scraped directly into scintillation vials, or subsequently eluted for further lipid analyses.

The identity of the radiolabel after incorporation into myocardial lipids was obtained by high-pressure liquid chromatography of the bromophenacyl derivatives $(13,18)$. The total myocardial cell lipid extract was concentrated under nitrogen, and saponified in $2 \mathrm{ml}$ of $10 \%$ methanolic $\mathrm{KOH}$ and $0.5 \mathrm{ml}$ of water. After incubation at $85^{\circ} \mathrm{C}$ for $1 \mathrm{~h}, 4 \mathrm{ml}$ of water were added. The fatty acids were obtained by three successive acidified ether extractions. The ether extracts were concentrated under $\mathrm{N}_{2}$ and resuspended in $2 \mathrm{ml}$ of acetonitrile, $20 \mu \mathrm{l}$ of dibromacetophenone $(0.2 \mu \mathrm{M})$, and $20 \mu \mathrm{l}$ of dicyclohexyl-18-crown ether $(0.02 \mu \mathrm{M})$, containing $45 \mathrm{mg}$ of solid $\mathrm{KHCO}_{3}$. After incubation at $85^{\circ} \mathrm{C}$ for $2 \mathrm{~h}$, the fatty acyl derivatives were filtered with a Waters SepPak (Waters Associates, Millford, MA), concentrated under nitrogen, resuspended in $500 \mu \mathrm{l}$ of acetonitrile, and injected directly into a Waters high-pressure liquid chromatograph. To achieve optimal separation of the fatty acyl species, an isocratic solvent of methanol/water/ acetonitrile (82:9:9) and a Supelco 5- $\mu$ l Lichrosorb C-18 reverse phase column (Supelco Inc., Bellefonte, PA) and a flow rate of $1.5 \mathrm{ml} / \mathrm{min}$ were utilized (19). Detection occurred at $254 \mathrm{~nm}$ and quantitation was performed by peak integration and comparison to a C-17 internal standard added to each sample. In some experiments, the eluate was collected for scintillation counting. In using these techniques, the recovery of exogenous arachidonate exceeded $90 \%$.

Metabolite assays. ATP levels were measured by high-pressure liquid chromatography of the $6 \%$ perchloric acid extracts of the cultured cells. The medium was removed from the dishes and the myocardial cells were rinsed two times with sterile saline. The cells were scraped directly into $1 \mathrm{ml}$ of ice-cold $6 \%$ perchloric acid, and the extracts were obtained by centrifugation. The time required to terminate each sample was $<25 \mathrm{~s}$. The extract was neutralized with $5 \mathrm{~N} \mathrm{KOH}$, filtered with a Waters SepPak, and injected directly into a Waters high-pressure liquid chromatograph. Quantitation and separation of the adenine nucleotides were accomplished with a Waters $10 \mu$ Bondapak C-18 reverse-phase column, as described previously (20). Creatine kinase in the medium was measured by spectrophotometric analysis (21). Because creatine kinase activity is unstable in dilute medium (21), these analyses were performed immediately after each experimental time point. Protein concentration was determined by the method of Lowry et al. (22). Data were normalized to the milligrams of protein content within each dish before the addition of metabolic inhibitors, as assessed by measurements performed on a matched set of control cell dishes.

Morphology. During these experiments, the myocardial cell cultures were observed for beating activity and shape changes using a Nikoninverted microscope (Nikon, Inc., Garden City, NY) with phasecontrast optics. For certain experiments, cells were grown on coverslips. Some coverslips were placed in enclosed chambers and the preparations were evaluated by real time and elapsed time cinemicroscopy. Other coverslips were placed in $3 \%$ glutaraldehyde in $0.1 \mathrm{M}$ phosphate buffer at the end of the experiments. Unstained cell preparations were examined by phase-contrast microscopy or with Nomarski optics. Other cell preparations were stained with oil-red-O, oil-red-O and hematoxylin, or toluidine blue before examination by phase-contrast and standard bright-field microscopy.

For electron microscopy, experiments were performed with cells grown directly on culture dishes. At the end of the experiments, the extracellular medium was replaced with ice-cold $3 \%$ glutaraldehyde in $0.1 \mathrm{M}$ phosphate buffer. In some experiments, the fixed cells were gently scraped from the plates prior to further processing; however, in most experiments, the cells were embedded while still attached to the plates. After fixation for several hours in glutaraldehyde, the preparations were rinsed several times with $0.1 \mathrm{M}$ phosphate buffer containing $5 \%$ sucrose. They were postfixed for $1 \mathrm{~h}$ in $1 \%$ osmium tetroxide in 0.1 $M$ phosphate buffer, dehydrated in a graded series of alcohols, and embedded in Luft's Epon 812 (Luft, Lincoln, MA) (23). Thin sections were cut on a Dupont-Sorvall MT 2 ultramicrotome (DuPont Instruments, Sorvall Biomedical Div., Newtown, CT) using a diamond knife. The sections were mounted on copper grids, and the preparations were stained with saturated alcoholic (20\%) uranyl acetate and Reynolds' lead citrate $(2.6 \%)(23)$. The preparations were examined and photographed with a JEOL $100 \mathrm{~S}$ transmission electron microscope (JEOL USA, Peabody, MA).

Statistical methods. Statistical analyses were performed by the two-tailed Student $t$ test. Results were considered significant when $P<0.05$.

\section{Results}

Morphology. Control cultures contained many aggregates of myocytes, which were observed to be beating regularly before fixation (Fig. $1 \mathrm{~A}$ ). After treatment of the myocardial cells with the combined inhibitors, deoxyglucose (DOG) ${ }^{1}$ and oli-

1. Abbreviations used in this paper: $\mathrm{CK}$, creatine kinase; $\mathrm{CN}$, cyanide; DOG, deoxyglucose; OLIGO, oligomycin. 

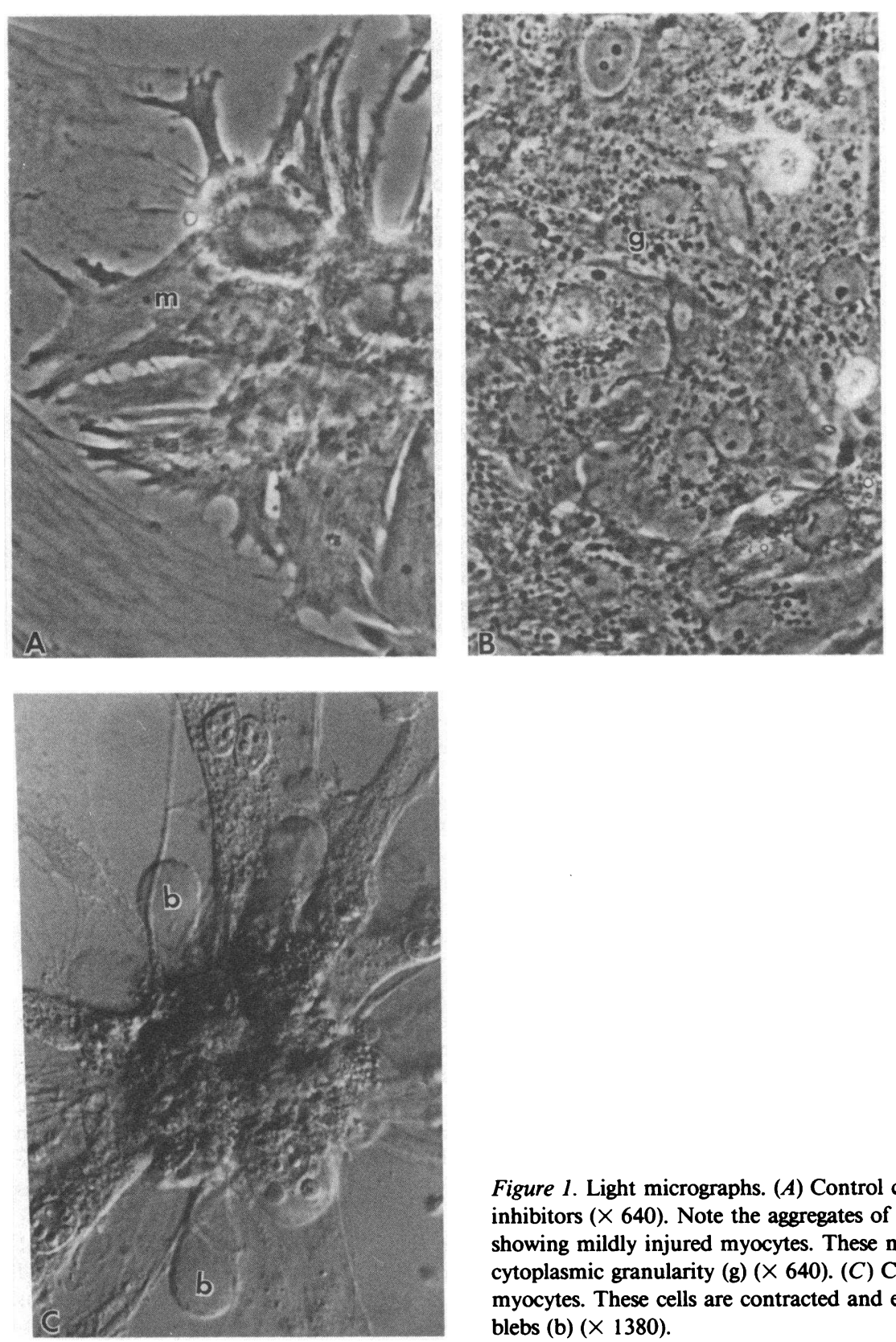

Figure 1. Light micrographs. (A) Control culture without metabolic inhibitors $(\times 640)$. Note the aggregates of myocytes $(m) .(B)$ Culture showing mildly injured myocytes. These myocytes exhibit increased cytoplasmic granularity $(\mathrm{g})(\times 640)$. $(C)$ Culture with severely injured myocytes. These cells are contracted and exhibit numerous surface blebs (b) $(\times 1380)$.

gomycin (OLIGO) or deoxyglucose and cyanide (CN), beating activity of myocytes ceased by $4 \mathrm{~h}$. The cytoplasm of the myocytes developed increased granularity (Fig. $1 B$ ). By $8 \mathrm{~h}$, many myocytes became markedly contracted, and some cells also showed focal vacuole formation (Fig. $1 C$ ). Contraction of the myocytes was accompanied by the formation of multiple sarcolemmal blebs, which protruded from the surfaces of the cells. Alternatively, some myocytes developed a single, large, raised, subsurface area (large bleb) along one side of the cell membrane. At this stage, the nuclei were shrunken, had condensed chromatin, and were surrounded by perinuclear halos. From 8 to $12 \mathrm{~h}$, more contracted cells with blebs and nuclear changes were observed. Also, many cells exhibited an additional phase of contraction which was associated with rupture of the blebs. In preparations exposed to DOG, $\mathrm{CN}$, or
OLIGO alone, changes were limited to reduction in beating activity. Features of severe cell injury were not observed.

In preparations exposed to iodoacetate $\left(0.3 \times 10^{-4} \mathrm{M}\right)$, a relatively rapid time course of cell injury occurred. By 1-2 h, beating activity ceased and many myocytes developed granular cytoplasm. By 2-4 h, severe cell injury became widespread, and the damaged myocytes showed features similar to those described for the DOG and OLIGO experiments.

Ultrastructural features of cell injury were generally similar with the different metabolic inhibitors. Control myocytes exhibited well-preserved organelles arranged in patterns typical of neonatal myocytes in culture (Fig. 2). At an early stage of injury, myocytes exhibited disruption of the normal arrangement of myofibrils and formation of a disorganized mass of myofilaments (contraction bands) (Figs. 3 and 4). Nuclei 


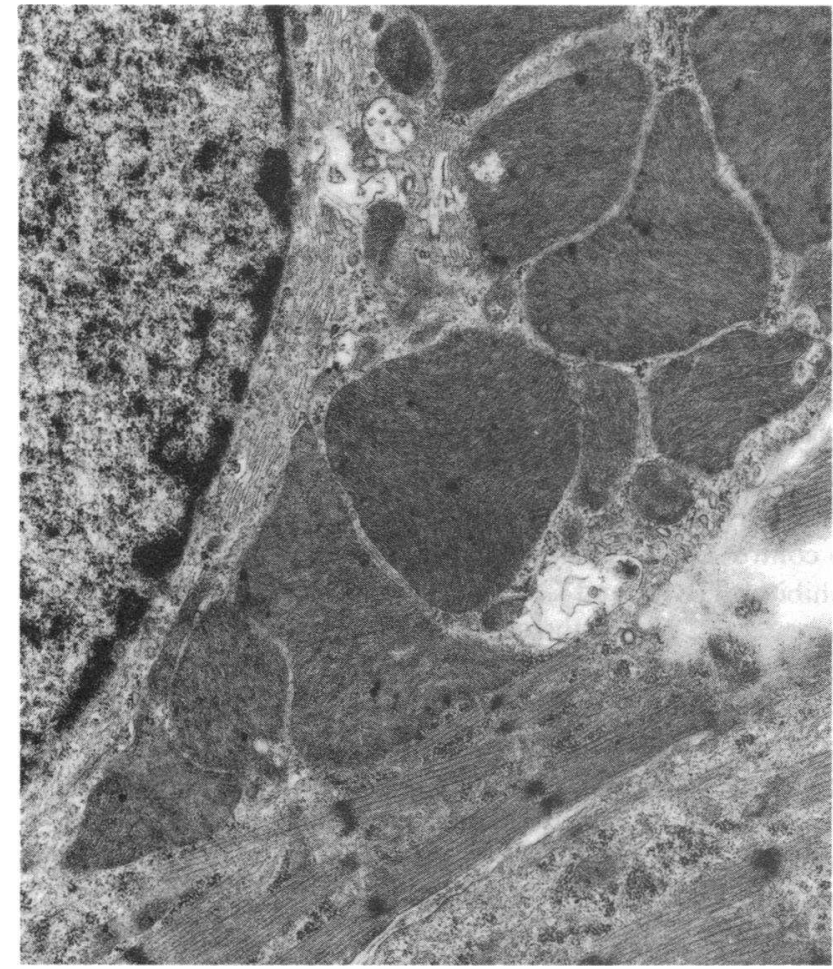

Figure 2. Electron micrograph of a myocyte from a control culture without metabolic inhibitors. The myocyte contains myofibrils, glycogen, and mitochondria with normal matrix granules $(\times 12,150)$. exhibited variable degrees of swelling and generally contained small to medium-sized amorphous matrix (flocculent) densities (Fig. $5 \mathrm{~A}$ ). Iodoacetate-treated cells exhibited particularly severe distortion of mitochondrial ultrastructure. No annular-granular densities indicative of early mitochondrial calcification were observed; however, the method of fixation used did not favor preservation of early calcific deposits (24). The subsarcolemmal blebs were filled with finely granular cytoplasm. The blebs also contained a few mitochondria, but organelles were generally sparse in the blebs (Fig. 5 B). Preparations at advanced stages of injury also contained variable numbers of completely disrupted and ruptured cells. The mitochondria in these cell fragments typically contained large amorphous matrix densities.

High-energy phosphate levels. The treatment of cultured myocardial cells with either glycolytic (16) or respiratory inhibitors (16) resulted in significant decreases in cellular ATP content versus control (Table I). As shown in Tables I and II, treatment with iodoacetate resulted in a time dependent decrease in ATP content of the cultured myocardial cells. After $4 \mathrm{~h}$ of treatment, there was over a $70 \%$ decrease in ATP content vs. control. If the metabolic inhibitor was removed after $1 \mathrm{~h}$ of treatment and replaced with fresh medium, the cells were able to regenerate a normal ATP level. However, after 2-4 $\mathrm{h}$ of exposure to iodoacetate, the myocardial cells were unable to regenerate a normal ATP content. Thus, the myocardial cells appeared to be reversibly injured after $1 \mathrm{~h}$ of treatment and irreversibly injured after $4 \mathrm{~h}$. Treatment with the combined metabolic inhibitors, DOG-OG or DOG-CN, also resulted in a time-dependent decrease in ATP content of
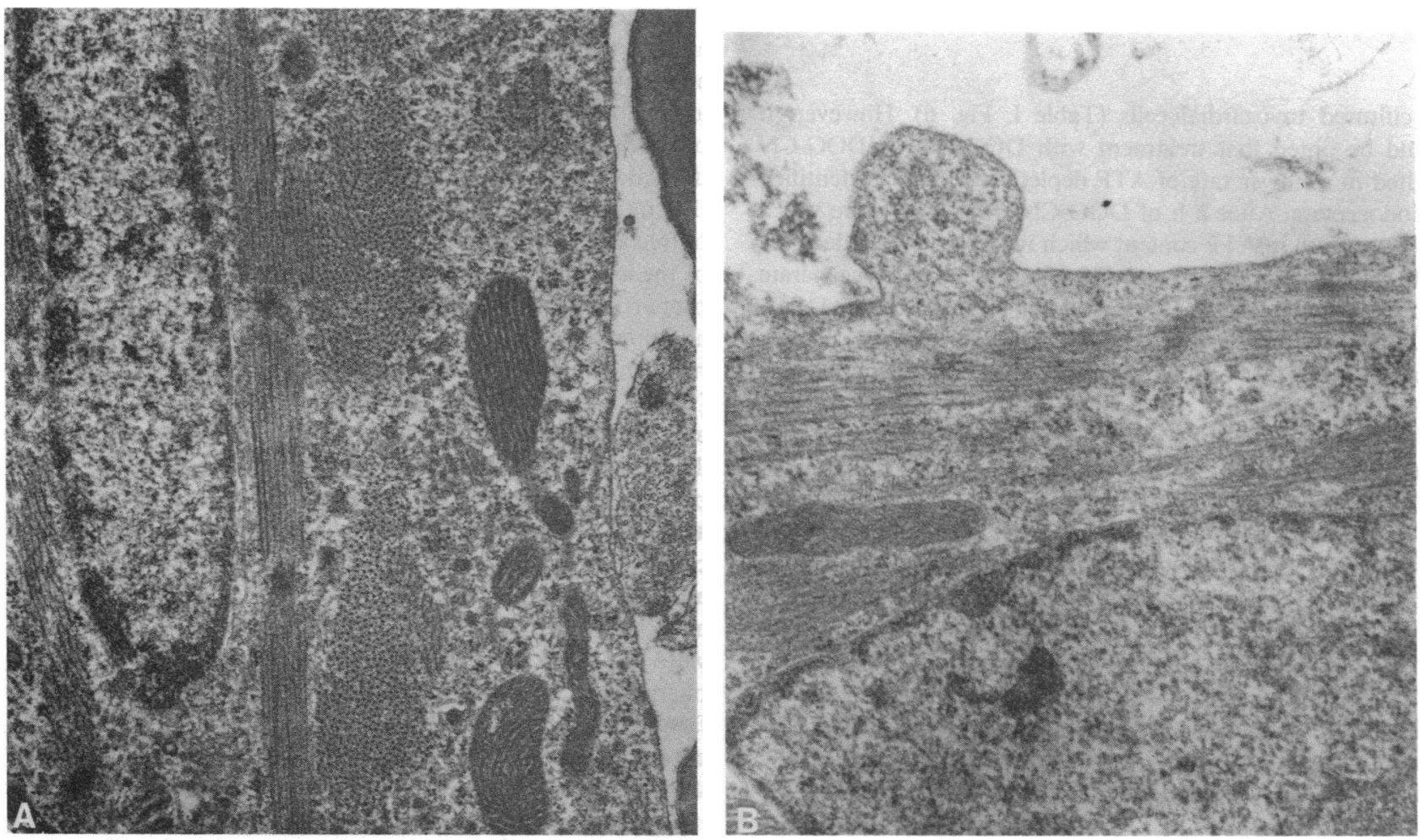

Figure 3. Electron micrograph of myocytes from culture exposed to iodoacetate $\left(0.3 \times 10^{-4} \mathrm{M}\right)$ for $1 \mathrm{~h}$. These myocytes exhibit mild alterations, including loss of normal mitochondrial matrix granules $(A)$ and early blebbing $(B) .(A) \times 20,000$. $(B) \times 25,800$. 


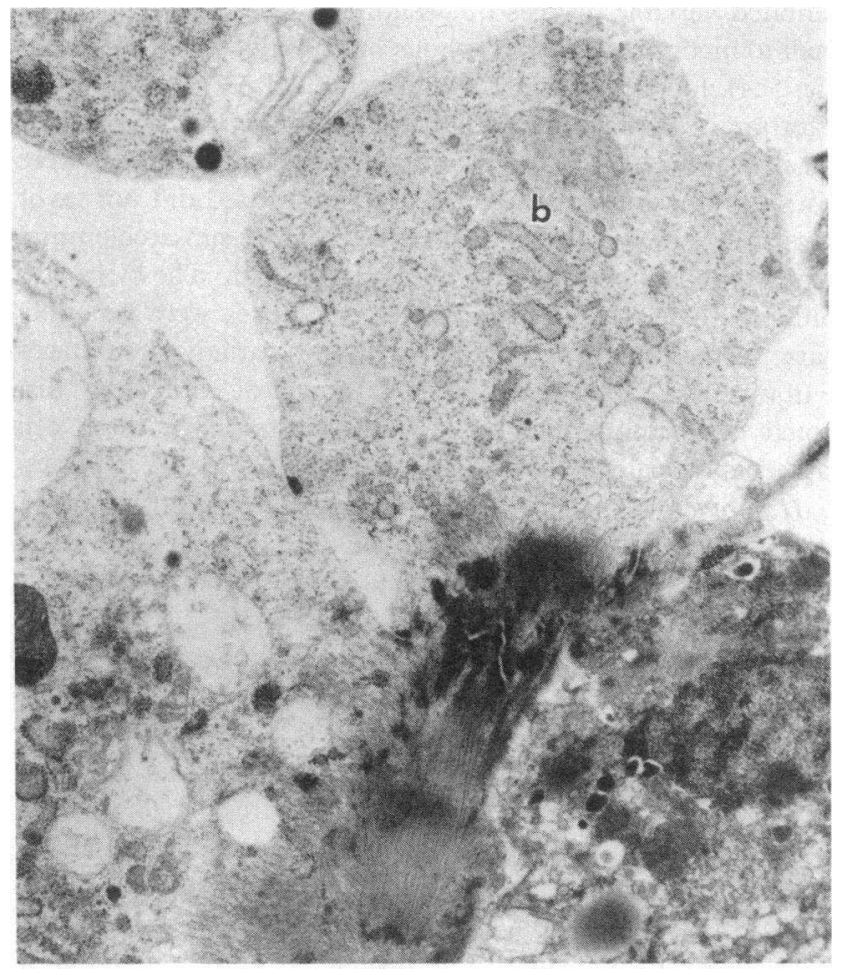

Figure 4. Electron micrograph of myocytes exposed to deoxyglucose and oligomycin for $\mathbf{8 h}$. The myocytes show marked contraction and disruption of the myofibrils with formation of tangled masses of myofilaments. The myocytes exhibit numerous surface blebs (b), which contain granular cytoplasm and a few mitochondria. The mitochondria are swollen and some contain amorphous matrix (flocculent) densities $(\times 12,500)$.

the cultured myocardial cells (Table I, Fig. 6). However, it should be noted that treatment with DOG-OG or DOG-CN resulted in a slower rate of $A T P$ depletion than that identified for iodoacetate. After $2 \mathrm{~h}$ of DOG-CN treatment, there was a $>25 \%$ decrease in ATP content which reached a $>70 \%$ decrease by $12 \mathrm{~h}$. Although the myocardial cells were able to regenerate a control level of ATP after 2-4 h of treatment with DOG$\mathrm{CN}$, the cells lost this ability after $12 \mathrm{~h}$ of treatment (Fig. 6). Thus, the time period of reversible injury was longer during DOG-CN treatment.

Creatine kinase release. The time course of the release of creatine kinase (CK) into the extracellular medium correlated with the previously described time course of ATP depletion and defective ATP resynthesis (Fig. 7). After $1 \mathrm{~h}$ of iodoacetate treatment, there was no statistically significant increase in CK release from the myocardial cells into the extracellular medium, but after $4 \mathrm{~h}$ of treatment, there was a greater than sixfold increase in CK release. Similarly, treatment with DOG-CN for $2 \mathrm{~h}$ resulted in no significant increase in CK release, but by $12 \mathrm{~h}$, there was a greater than sixfold increase. In addition, it should be noted that the initial release of $\left[{ }^{3} \mathrm{H}\right]$ arachidonate acid at $4 \mathrm{~h}$ preceded the initial release of creatine kinase activity. This lag period of CK release suggests that the release of arachidonate may immediately precede the development of sarcolemmal membrane permeability defects.

$\left[{ }^{3} \mathrm{H}\right]$ arachidonate release. The addition of $\left[{ }^{3} \mathrm{H}\right]$ arachidonate to the extracellular medium of the cultured cells resulted in the incorporation of the exogenous radiolabeled fatty acid into myocardial cell lipids (Table III). Over $70 \%$ of the $\left[{ }^{3} \mathrm{H}\right]$ arachidonate was found in phosphatidylethanolamine, phosphatidylcholine, phosphatidylserine, and phosphatidylinositol. Treatment with either iodoacetate, DOG-OG, or DOG$\mathrm{CN}$ resulted in a time-dependent release of $\left[{ }^{3} \mathrm{H}\right]$ arachidonate from the myocardial cells into the extracellular medium. The time course of release of $\left[{ }^{3} \mathrm{H}\right]$ arachidonate correlated with the development of functional membrane permeability alterations as assessed by the release of $\mathrm{CK}$ into the extracellular medium (Fig. 8). After $1 \mathrm{~h}$ of iodoacetate treatment, there was no statistically significant increase in $\left[{ }^{3} \mathrm{H}\right]$ arachidonate release, but after $4 \mathrm{~h}$, there was a greater than sixfold increase compared to control cells. After treatment with the combined metabolic inhibitors, DOG and $\mathrm{CN}$, there was no statistically significant increase at $2 \mathrm{~h}$, but there was a greater than $2 \frac{1}{2}-$-fold increase after $12 \mathrm{~h}$ of treatment. It should be noted that at $4 \mathrm{~h}$, there was a borderline increase of $\left[{ }^{3} \mathrm{H}\right]$ arachidonate release, which presumably represented myocardial cells that were in the process of becoming severely injured.

As shown in Table III, unesterified arachidonate accounted for $>66 \%$ of the radioactivity released from the myocardial cells into the extracellular medium after treatment with either iodoacetate for $4 \mathrm{~h}$ or combined deoxyglucose and cyanide treatment for $12 \mathrm{~h}$. Thus, the release of radioactivity from these cells into the extracellular medium did not simply represent detachment of the cells into the medium, but rather deacylation of the radiolabeled fatty acid from the myocardial cell lipids. In addition, there was quantitative recovery of the radiolabeled fatty acid throughout the entire chromatographic procedure as evidenced by a $>85 \%$ recovery (Table III). Phospholipids were the major esterified source of the free arachidonate, with phosphatidylcholine and phosphatidylethanolamine being the major sources. The release of radiolabeled arachidonate cannot be explained on the basis of the hydrolysis of triacylglycerol, because there was no statistically significant decrease in the $\left[{ }^{3} \mathrm{H}\right]$ arachidonate content of triacylglycerol in the cultured myocardial cells when there was significant release of free arachidonate into the extracellular medium. The source of the arachidonate was from myocytes and not from a small proportion of contaminating nonmyocardial cells, in that the addition of iodoacetate for $4 \mathrm{~h}$ to cultures enriched in nonmyocardial cells $(90 \%)$ resulted in proportionately less $\left[{ }^{3} \mathrm{H}\right]$ arachidonate release $(25 \%$ increase vs. control) in spite of a similar level of ATP depletion ( $>80 \%$ decrease vs. control). To ensure that the radiolabeled arachidonate at the end of the period of incubation had not been converted to other fatty acids by either chain shortening, desaturation, or oxidation, cultured myocardial cells were labeled with $\left[{ }^{3} \mathrm{H}\right]$ arachidonate and $\left[{ }^{14} \mathrm{C}\right]$ palmitate and subsequently treated with deoxyglucose and cyanide for $12 \mathrm{~h}$. At that time, the myocardial cell lipids were extracted and subsequently derivatized with a bromophenacyl group, as described previously (17). The derivatized fatty acids were separated subsequently by high-pressure liquid chromatography. Nonradioactive fatty acids were detected by ultraviolet absorption at $254 \mathrm{~nm}$, whereas the origin of the radiolabel was identified by collecting fractions of the column eluate for ${ }^{14} \mathrm{C}$ - or ${ }^{3} \mathrm{H}$-activity. As shown in Fig. 9, >90\% of the ${ }^{3} \mathrm{H}$-activity was still in the form of $\left[{ }^{3} \mathrm{H}\right]$ arachidonate and $>95 \%$ of the ${ }^{14} \mathrm{C}$-activity was in the form of $\left[{ }^{14} \mathrm{C}\right]$ palmitic acid. Thus, 

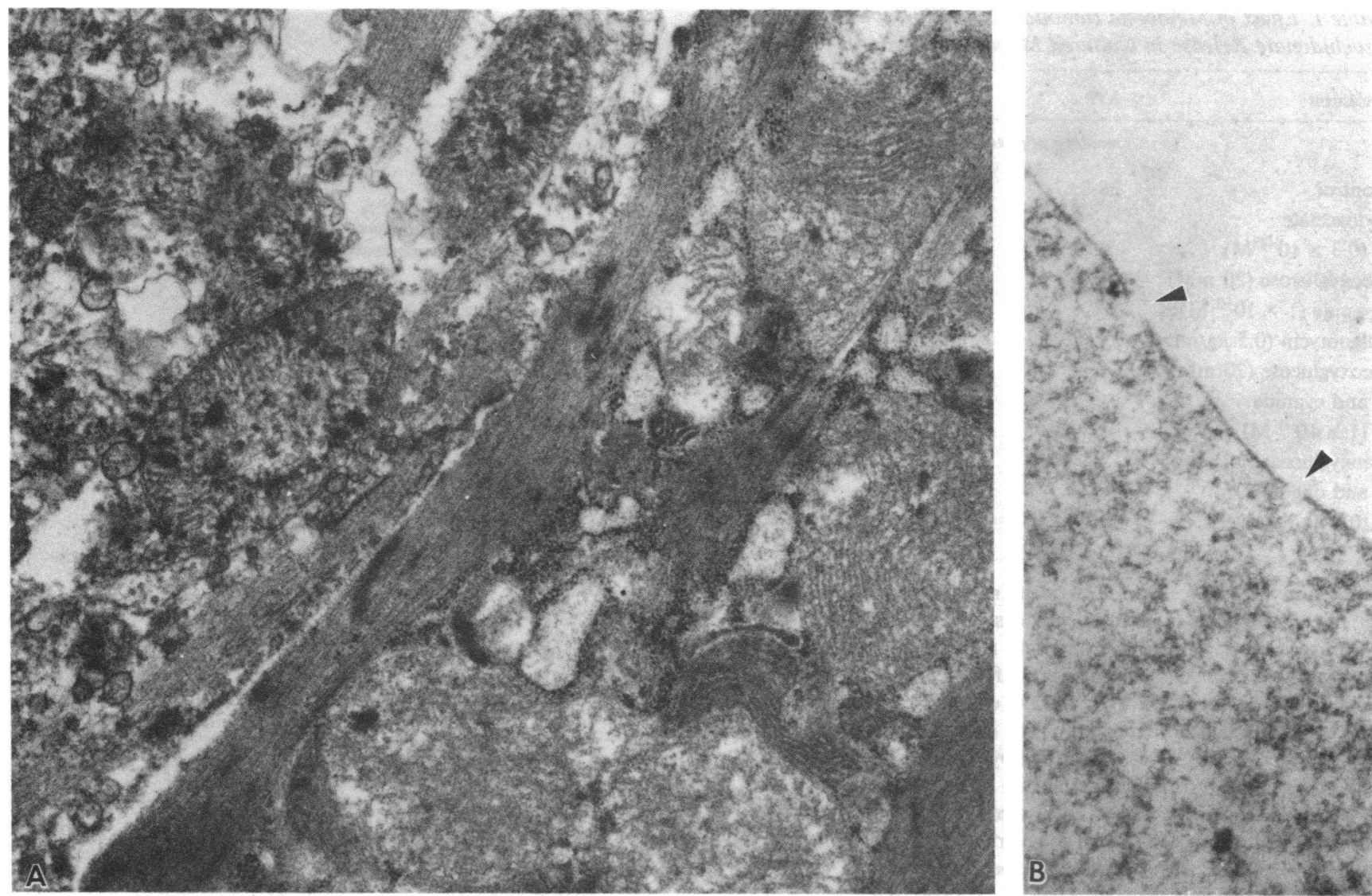

Figure 5. Electron micrographs showing selected features of severely damaged cells. $(A)$ The mitochondria are swollen and have clear matrices, distorted cristae, and amorphous matrix (flocculent) densi- ties $(\times 20,000) .(B)$ The sarcolemmal lining of a surface bleb exhibits focal discontinuities $(\times 45,000)$. there was minimal conversion of the radiolabeled fatty acids to other fatty acyl moieties during these experiments.

To further examine the relationship between the degradation of phospholipids and the development of membrane defects, cultured neonatal myocardial cells were exposed to various concentrations of iodoacetate. As shown in Fig. 10, increasing concentrations of iodoacetate resulted in a corresponding increase in the release of arachidonate into the extracellular medium. Table IV displays the effects of increasing concentrations of iodoacetate on CK release. After $2 \mathrm{~h}$ of treatment with increasing concentrations of iodoacetate, there was a graded effect on CK release that corresponded to the extent of $\left[{ }^{3} \mathrm{H}\right]$ arachidonate release (Fig. 10).

\section{Discussion}

Although previous studies have demonstrated that phospholipid degradation is causally related to the loss of cell viability in ischemic liver (7-9), there have been several problems with directly extrapolating from the data found in ischemic liver to ischemic heart. First, after $1 \mathrm{~h}$ of fixed left anterior descending coronary artery occlusion in an open-chest, anesthetized canine model, there was unequivocal evidence of irreversible myocardial injury that was not accompanied by significant decreases in total phospholipid content (6). In these studies, we found that the myocardial cell has a much slower rate and lower extent of phospholipid depletion during ischemia compared to the ischemically injured liver cell $(6,8)$. Second, Steenburgen and Jennings have found that the accumulation of lysophosphatides, phospholipid degradation products, does not correlate with the development of sarcolemmal defects in canine heart slices during conditions of autolysis (25). Third, although some studies have demonstrated that pretreatment with chlorpromazine, a putative phospholipase inhibitor, protects ischemic myocardium (26-28) in others, chlorpromazine has failed to be similarly protective (29).

To clarify the role of phospholipid degradation in the development of membrane defects and irreversible myocardial cell injury, it appeared that at least three factors would need to be considered. These factors are $(a)$ the use of a myocardial model that contained a maximal number of myocytes compared to interstitial cells and where the structure and function of the myocardial cells could be examined over extended periods of time, $(b)$ the utilization of a sensitive measure of phospholipid degradation, and $(c)$ the evaluation of a uniform stimulus for ATP depletion. For these reasons, the current study utilized cultured neonatal rat heart cells to explore the relationship between membrane phospholipid degradation and the progression of cell injury during ATP depletion. The cultured myocardial cell model offers several important advantages for our studies. First, it employs myocardial cells that beat synchronously in culture where cell injury can be monitored for 
Table I. Effect of Metabolic Inhibitors on ATP Depletion and Arachidonate Release in Cultured Myocardial Cells

\begin{tabular}{lll}
\hline Treatment & ATP & Arachidonate \\
\hline & $n m o l / m g$ of protein & $c p m \times 10^{-3} / \mathrm{mg}$ of protein \\
Control & $38.8 \pm 7.5$ & $27.1 \pm 1.0$ \\
$\begin{array}{l}\text { lodoacetate } \\
\left(0.3 \times 10^{-4} \mathrm{M}\right)\end{array}$ & $0.4 \pm 0.1^{*}$ & $135.5 \pm 5.0^{*}$ \\
Deoxyglucose $(20 \mathrm{mM})$ & $19.1 \pm 3.6^{*}$ & $29.7 \pm 3.3$ \\
$\begin{array}{l}\text { Cyanide }\left(1 \times 10^{-3} \mathrm{M}\right) \\
\text { Oligomycin }(0.5 \mu \mathrm{g} / \mathrm{ml})\end{array}$ & $20.2 \pm 1.2^{*}$ & $27.1 \pm 0.8$ \\
$\begin{array}{l}\text { Deoxyglucose }(20 \mathrm{mM}) \\
\text { and cyanide } \\
\left(1 \times 10^{-3} \mathrm{M}\right)\end{array}$ & & $20.9 \pm 0.4$ \\
$\begin{array}{l}\text { Deoxyglucose }(20 \mathrm{~mm}) \\
\text { and oligomycin } \\
(0.5 \mu \mathrm{g} / \mathrm{ml})\end{array}$ & $2.4 \pm 0.1^{*}$ & $61.0 \pm 2.0^{*}$ \\
\hline
\end{tabular}

Cultured myocardial cells from neonatal rat hearts were labeled with $\left[{ }^{3} \mathrm{H}\right]$ arachidonate as described in Methods. After $24 \mathrm{~h}$, the radioactive medium was removed and replaced with medium containing various concentrations of metabolic inhibitors. After $12 \mathrm{~h}$, the extracellular medium was extracted for lipids and the unesterified fatty acids separated by thin layer chromatography. The cells were extracted with $6 \%$ perchloric acid and ATP was measured by high-pressure liquid chromatography of the neutralized extract. In separate experiments, the myocardial cells were processed for electron microscopy and the degree of cellular injury was graded as described in Methods. Results are the mean \pm SEM of three or more experiments.

$* P<0.05$ vs. control.

several hours during ATP depletion. Although it would be optimal to use adult heart cells, it is difficult to maintain adult heart cells in culture for extended periods of time, and they do not beat synchronously in culture (30). Second, quantitative recovery of the radiolabeled arachidonate is possible by extracting both the extracellular medium and the myocardial cells, thereby possibly providing a more sensitive index of membrane

Table II. Myocardial ATP Levels during Iodoacetate Treatment

\begin{tabular}{lll}
\hline & \multicolumn{1}{l}{ ATP } \\
\cline { 2 - 3 } Time & Unwashed & Washed \\
\hline$h$ & $n m o l / m g$ cell of protein & nmol/mg cell of protein \\
0 & $35.04 \pm 2.11$ & $36.39 \pm 1.74$ \\
1 & $27.18 \pm 2.64^{*}$ & $33.73 \pm 3.80$ \\
2 & $13.26 \pm 4.19^{*}$ & $4.58 \pm 0.69^{*}$ \\
4 & $9.64 \pm 1.35^{*}$ & $1.28 \pm 0.27^{*}$ \\
\hline
\end{tabular}

Cultured myocardial cells were grown to confluency over $72 \mathrm{~h}$ and subsequently incubated with iodoacetate $\left(0.3 \times 10^{-4} \mathrm{M}\right)$ for various time periods. At the end of iodoacetate treatment, the cells were extracted with 6\% perchloric acid and ATP was measured by high-pressure liquid chromatography (unwashed). In a matched set of cell dishes, the extracellular medium was removed and replaced with fresh medium and the cells were allowed a 24-h time period to regenerate ATP levels (washed). Values are expressed as the mean \pm SEM for $n=3$ or greater experiments.

$* P<0.05$ vs. control.

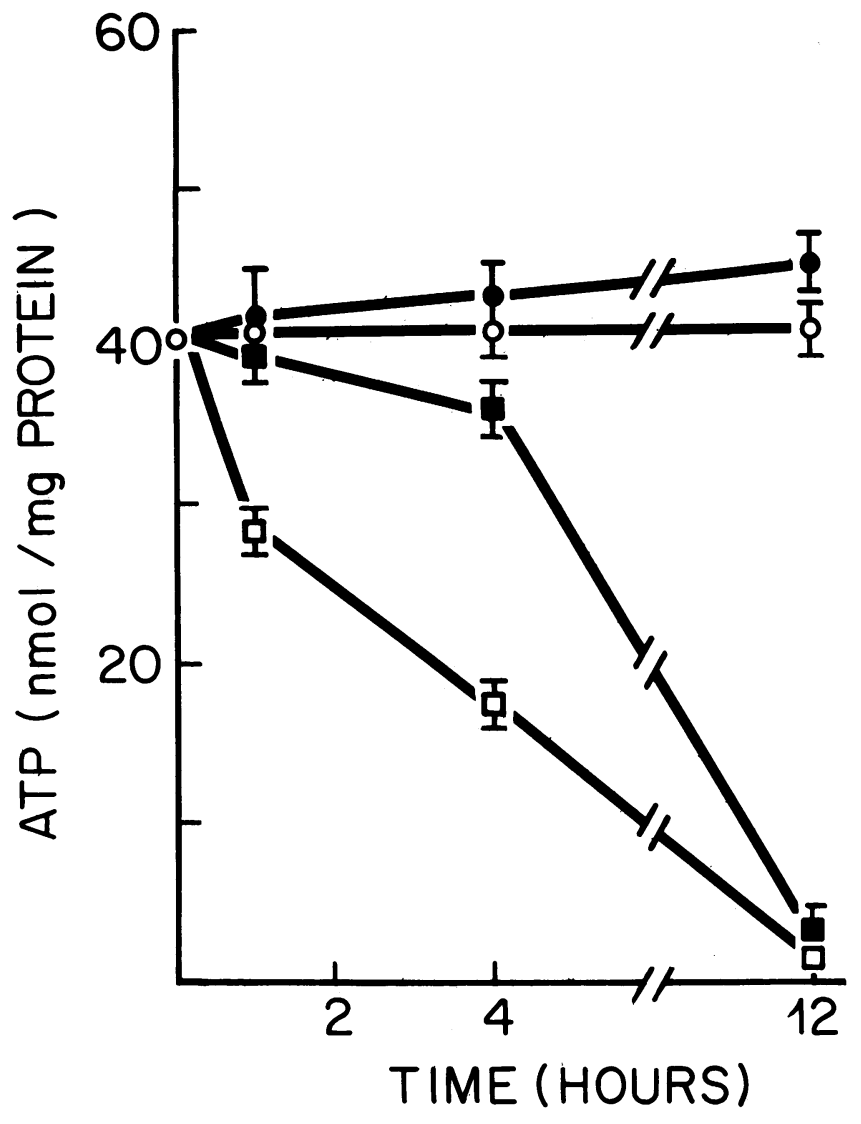

Figure 6. Myocardial cell ATP levels during combined deoxyglucose $(20 \mathrm{mM})$ and cyanide $\left(1 \times 10^{-3}\right)$ treatment. Myocardial cells were plated on $60-\mathrm{mm}$ cell dishes and grown to confluency over $72 \mathrm{~h}$. The medium was removed and fresh medium containing deoxyglucose and cyanide (squares) was added. A separate set of matched control cell dishes was placed in the medium without metabolic inhibitors (circles). After various time periods, a portion of the cell dishes was immediately taken for ATP analysis (open symbols), while another portion was placed in fresh medium without inhibitors (solid figures). After a 24-h time period to allow the possible regeneration of ATP, the cells were harvested for ATP analyses. Results are the mean \pm SEM for $n=3$ or greater experiments.

phospholipid perturbation than measurements of total phospholipid content. Third, cultured cells have a higher myocardial cell content than intact heart. Previous studies demonstrated that $>70 \%$ of the cells in the intact heart are nonmyocardial cells (31). To measure the contribution of nonmyocardial cells to arachidonate release, cultures containing different ratios of myocardial and nonmyocardial cells can be obtained. Fourth, the isolated myocardial cells may be exposed to constant concentrations of exogenous catecholamines and other hormones. Studies in several animal models have demonstrated redistribution and release of catecholamines during myocardial ischemia (32), which could have independent effects on myocardial cell lipid metabolism distinct from the effects of highenergy phosphate depletion.

In that previous studies have demonstrated that neonatal myocytes are more dependent on glycolysis than adult heart cells (33), there is an inherent difficulty in utilizing cultured neonatal rat myocardial cells as a model to simulate alterations 


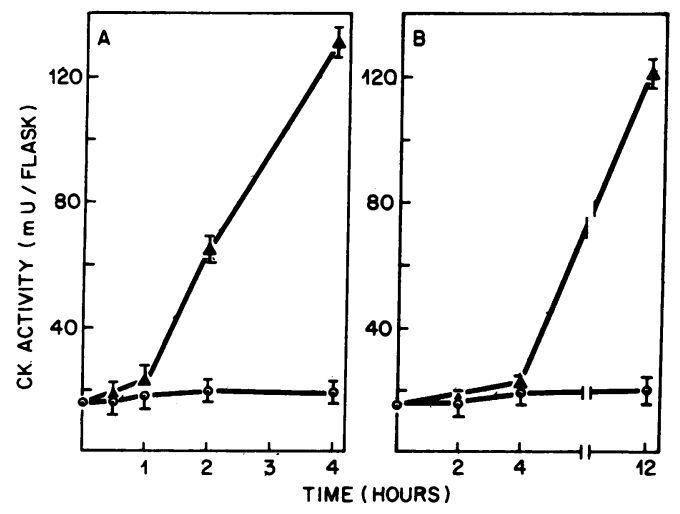

Figure 7. Time course of release of CK activity into the extracellular medium during treatment with iodoacetate $\left(0.3 \times 10^{-4} \mathrm{M}\right)$ or combined deoxyglucose $(20 \mathrm{mM})$ and cyanide $\left(1 \times 10^{-3} \mathrm{M}\right)$. Cultured myocardial cells are grown to confluency and labelled with $\left[{ }^{3} \mathrm{H}\right.$ ]arachidonate for $24 \mathrm{~h}$. The radioactive medium was subsequently removed and replaced with fresh medium containing either iodoacetate alone $(A)$ or combined deoxyglucose-cyanide $(B)$. In each set of experiments, a matched set of control cell dishes received medium without inhibitors. After various time periods, the medium was removed and processed for $\mathrm{CK}$ and $\left[{ }^{3} \mathrm{H}\right]$ arachidonate content as described in Methods. Results are the mean \pm SEM for $n=3$ or greater experiments. ( $\triangle)$ Inhibitor; $(\odot)$ control.

that occur during myocardial ischemia. Thus, it should be expected that neonatal myocytes are more resistant than adult myocytes to oxygen deprivation. To obviate this difficulty, the present study utilized inhibitors of glycolysis and mitochondrial respiration to deplete high-energy phosphate levels. By using a variety of inhibitors, this model offered the opportunity to

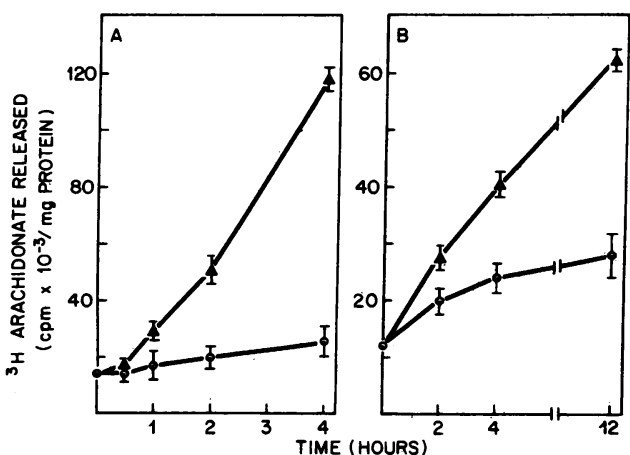

Figure 8. Time course of release of $\left[{ }^{3} \mathrm{H}\right]$ arachidonate into the extracellular medium during treatment with iodoacetate $\left(0.3 \times 10^{-4} \mathrm{M}\right)$ $(A)$ or combined deoxyglucose $(20 \mathrm{mM})$ and cyanide $\left(1 \times 10^{-3} \mathrm{M}\right)$ (B). Experimental details are identical to Fig. 7. Results are the mean \pm SEM for $n=3$ or greater experiments.

examine the effects of ATP depletion on the deacylation of arachidonate and the loss of cell viability when either glycolysis or fatty acid oxidation were impaired. Previous studies have demonstrated that neonatal myocytes react similarly to the adult heart when both glycolysis and fatty acid oxidation are inhibited $(34,35)$. However, it should be noted that the direct relevance of this cultured cell model to in vivo ischemia remains to be determined. ATP depletion is only one of many biochemical alterations that occur during in vivo ischemia. Furthermore, each of these metabolic inhibitors may have additional effects on myocardial cells beyond simply the induction of ATP depletion. Iodoacetate acts by inhibiting glyceraldehyde-3-phosphate dehydrogenase, but it may also inactivate many thiol containing enzymes. Oligomycin B may

Table III. Distribution of $\left[{ }^{3} \mathrm{H}\right]$ Arachidonate in Cultured Myocardial Cells and Extracellular Medium After Treatment with Metabolic Inhibitors

\begin{tabular}{|c|c|c|c|c|c|c|c|c|c|c|c|c|}
\hline \multirow{3}{*}{$\begin{array}{l}\text { Treatment } \\
\text { and time }\end{array}$} & \multicolumn{6}{|l|}{ Cells } & \multicolumn{6}{|l|}{ Medium } \\
\hline & \multicolumn{6}{|c|}{ Metabolic inhibitor } & \multicolumn{6}{|c|}{ Metabolic inhibitor } \\
\hline & TLE & PC & PE & $\mathbf{P S}+\mathbf{P I}$ & TG & FFA & TLE & $\mathrm{PC}$ & PE & PI & TG & FFA \\
\hline$h$ & \multicolumn{6}{|c|}{$\mathrm{cpm} \times 10^{-2} / \mathrm{mg}$ of protein } & \multicolumn{6}{|c|}{$\mathrm{cpm} \times 10^{-2} / \mathrm{mg}$ of protein } \\
\hline $\begin{array}{c}\text { Control } \\
4\end{array}$ & $\begin{array}{l}2,190 \pm 25 \\
(96 \%)\end{array}$ & $\begin{array}{l}625 \pm 30 \\
(27)\end{array}$ & $\begin{array}{l}770 \pm 28 \\
(34)\end{array}$ & $\begin{array}{l}216 \pm 9.3 \\
(9.4)\end{array}$ & $\begin{array}{l}133 \pm 10.3 \\
(5.7)\end{array}$ & $\begin{array}{l}36 \pm 3.5 \\
(1.6)\end{array}$ & $\begin{array}{c}103 \pm 1.5 \\
(4.0)\end{array}$ & $\begin{array}{l}5.8 \pm 0.5 \\
(0.2)\end{array}$ & $\begin{array}{l}7.5 \pm 0.7 \\
(0.3)\end{array}$ & $\begin{array}{l}3.5 \pm 0.37 \\
(0.15)\end{array}$ & $\begin{array}{l}4.3 \pm 0.7 \\
(0.18)\end{array}$ & $\begin{array}{c}92.5 \pm 10 \\
(4.0)\end{array}$ \\
\hline $\begin{array}{l}\text { Iodoacetate } \\
4\end{array}$ & $\begin{array}{l}1,440 \pm 25 \\
(67)\end{array}$ & $\begin{array}{l}390 \pm 14 \\
(18)\end{array}$ & $\begin{array}{l}462 \pm 18 \\
(21)\end{array}$ & $\begin{array}{l}135 \pm 6 \\
(6.2)\end{array}$ & $\begin{array}{l}120 \pm 1.3 \\
(5.5)\end{array}$ & $\begin{array}{l}51 \pm 2.1 \\
(2.4)\end{array}$ & $\begin{array}{l}720 \pm 8.5 \\
(33)\end{array}$ & $\begin{array}{l}36.5 \pm 1.5 \\
(1.7)\end{array}$ & $\begin{array}{l}52.5 \pm 5 \\
(2.4)\end{array}$ & $\begin{array}{l}31.3 \pm 1.3 \\
(1.4)\end{array}$ & $\begin{array}{l}17.5 \pm 0.9 \\
(0.8)\end{array}$ & $\begin{array}{l}613 \pm 18 \\
(28)\end{array}$ \\
\hline $\begin{array}{c}\text { Control } \\
12\end{array}$ & $\begin{array}{l}2,205 \pm 23 \\
(92 \%)\end{array}$ & $\begin{array}{l}580 \pm 27 \\
(24)\end{array}$ & $\begin{array}{l}773 \pm 21 \\
(32)\end{array}$ & $\begin{array}{l}212 \pm 10 \\
(8.8)\end{array}$ & $\begin{array}{l}120 \pm 1.1 \\
(4.9)\end{array}$ & $\begin{array}{l}27.5 \pm 1.0 \\
(1.1)\end{array}$ & $\begin{array}{c}162 \pm 5 \\
(8.0)\end{array}$ & $\begin{array}{l}7.0 \pm 0.5 \\
(0.3)\end{array}$ & $\begin{array}{l}9.3 \pm 2.5 \\
(0.4)\end{array}$ & $\begin{array}{l}5 \pm 0.5 \\
(0.2)\end{array}$ & $\begin{array}{l}4 \pm 0.5 \\
(0.6)\end{array}$ & $\begin{array}{l}127 \pm 5.3 \\
(5.3)\end{array}$ \\
\hline $\begin{array}{c}\text { DOG-CN } \\
12\end{array}$ & $\begin{array}{l}1,630 \pm 32 \\
(77)\end{array}$ & $\begin{array}{l}450 \pm 25 \\
(21)\end{array}$ & $\begin{array}{l}497 \pm 9 \\
(24)\end{array}$ & $\begin{array}{l}137 \pm 4 \\
(6.6)\end{array}$ & $\begin{array}{l}162 \pm 6 \\
(7.8)\end{array}$ & $\begin{array}{l}0.4 \pm 1.3 \\
(2.0)\end{array}$ & $\begin{array}{l}485 \pm 4.3 \\
(23)\end{array}$ & $\begin{array}{l}24 \pm 3 \\
(1.2)\end{array}$ & $\begin{array}{l}55.5 \pm 5 \\
(2.7)\end{array}$ & $\begin{array}{l}17 \pm 1.3 \\
(0.8)\end{array}$ & $\begin{array}{l}13.8 \pm 0.3 \\
(0.6)\end{array}$ & $\begin{array}{l}412 \pm 10 \\
(19)\end{array}$ \\
\hline
\end{tabular}

Cultured myocardial cells were labeled with $\left[{ }^{3} \mathrm{H}\right]$ arachidonate as described in Methods. After a 24-h labeling period, the radioactive medium was removed and replaced with fresh medium containing either no additions (control), iodoacetate $\left(0.3 \times 10^{-4} \mathrm{M}\right)$, or combined deoxyglucose (20 $\mathrm{mM})$ and cyanide $\left(1 \times 10^{-3} \mathrm{M}\right)$. After various time periods, the cells and medium were extracted for lipid. The various lipid classes were isolated by thin-layer chromatography as described in Methods. Parentheses refer to the percentage that each component comprises of the ${ }^{3} \mathrm{H}-$ activity present in the total extract of the cells and the medium. Results are the mean \pm SEM for $n=3$ or greater experiments. Abbreviations: TLE, total lipid extract; PC, phosphatidylcholine; PE, phosphatidylethanolamine; PS and PI, phosphatidylserine plus phosphatidylinositol; TG, triacylglycerol. 

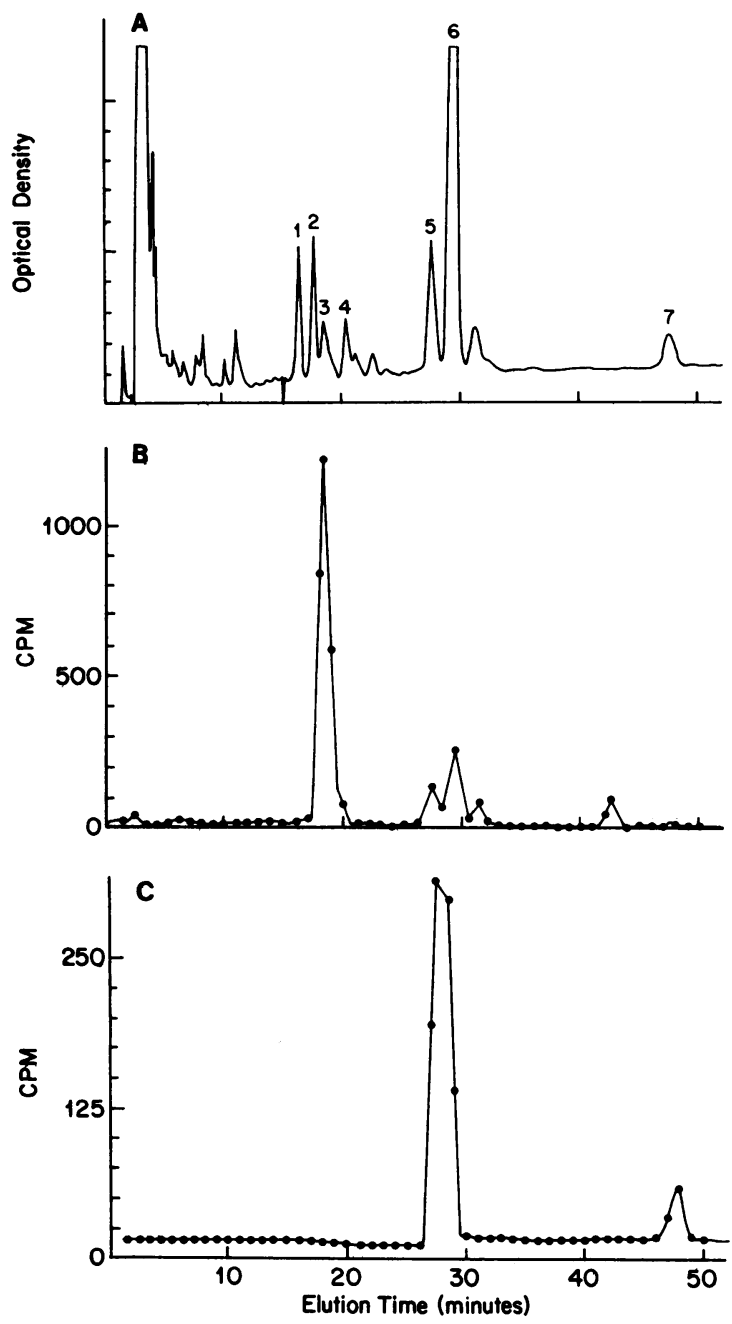

Figure 9. Separation of bromophenacyl fatty acid derivatives obtained from cultured myocardial cells radiolabeled with $\left[{ }^{3} \mathrm{H}\right]$ arachidonate and $\left[{ }^{14} \mathrm{C}\right]$ palmitate. Cultured myocardial cells were radiolabeled with $\left[{ }^{3} \mathrm{H}\right]$ arachidonate and $\left[{ }^{14} \mathrm{C}\right]$ palmitate and the lipids were extracted by the method of Bligh and Dyer (17). The bromophenacyl fatty acid derivatives of the total lipid extract were synthesized and separated by high pressure liquid chromatography as described in Methods. $(A)$ Ultraviolet absorption at $254 \mathrm{~nm} ;(B){ }^{3} \mathrm{H}$-activity of eluate; $(C){ }^{14} \mathrm{C}$-activity of eluate. 3 , arachidonate; 5 , palmitate.

be a potent inhibitor of oxidative phosphorylation blocking mitochondrial ATP formation, but it may also create hydrophilic channels across membranes which may influence transmembrane potential and salt balance. Deoxyglucose may inhibit glycoprotein formation by substitution for mannose resulting in the formation of dolichol monophosphate deoxyglucose.

Previous studies in a perfused rabbit septal model have suggested that membrane dysfunction can occur within seconds of the induction of hypoxia (36). In this model, a large leak of potassium occurs immediately after the removal of oxygen (36). However, membrane alterations occurring early in the course of cell injury appear to involve dysfunction of specific membrane ion pumps and channels, rather than a more generalized and nonspecific increase in membrane permeability, which occurs in later stages of cell injury (3).

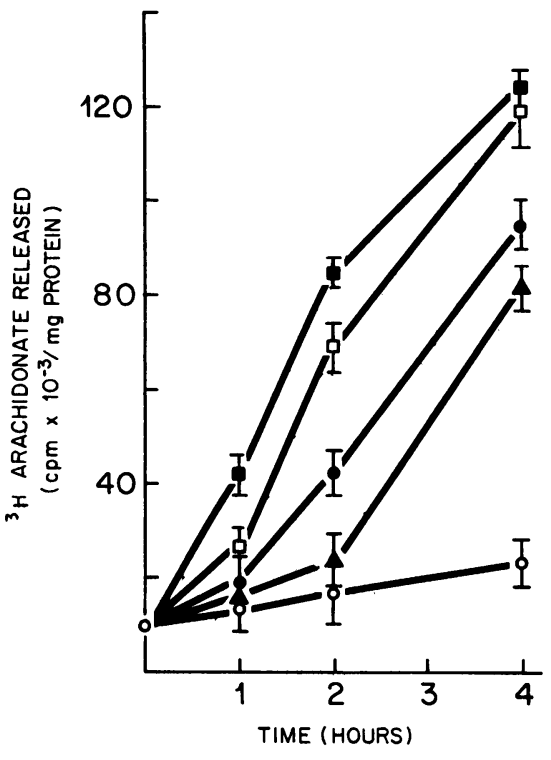

Figure 10. Effect of increasing concentrations of iodoacetate on the time course of release of $\left[{ }^{3} \mathrm{H}\right]$ arachidonate from cultured myocardial cells. Experimental details are identical to Fig. 3 with the exception that various concentrations of iodoacetate were utilized. (O) Control; (A) $0.2 \times 10^{-4} \mathrm{M}$; (๑) $0.3 \times 10^{-4} \mathrm{M}$; () $0.4 \times 10^{-4} \mathrm{M}$; (D) $1 \times 10^{-4}$ M. Results are mean \pm SEM for $n=3$ or greater experiments.

By using this cultured myocardial cell model, the current study demonstrated a relationship between the release of radiolabeled arachidonate from membrane phospholipids, the development of sarcolemmal blebs, and the loss of cell viability. The loss of cell viability was manifest by $(a)$ the release of creatine kinase into the extracellular medium, $(b)$ the development of light and electron microscopic evidence of irreversible cell injury, and $(c)$ the inability of the myocardial cells to regenerate ATP levels to control values on removal of the metabolic inhibitors. The relationships were evidenced during treatment with either glycolytic or respiratory inhibitors, and thus were not dependent on the inhibition of fatty acid oxidation. Those metabolic inhibitors that were unable to decrease ATP content below $40 \%$ of control were unable to

Table IV. Release of CK Activity into the

Extracellular Medium After Treatment with Various Concentrations of Iodoacetate for $2 \mathrm{H}$

\begin{tabular}{lc}
\hline Treatment & CK release \\
\hline & mU/flask \\
Control & $9.07 \pm 2.75$ \\
Iodoacetate & \\
$\left(0.2 \times 10^{-4} \mathrm{M}\right)$ & $21.42 \pm 3.78$ \\
$\left(0.3 \times 10^{-4} \mathrm{M}\right)$ & $64.16 \pm 4.82^{*}$ \\
$\left(0.4 \times 10^{-4} \mathrm{M}\right)$ & $115.78 \pm 18.10^{*}$ \\
$\left(1 \times 10^{-4} \mathrm{M}\right)$ & $153.34 \pm 18.80^{*}$
\end{tabular}

Experimental details are similar to Fig. 10. Values represent the mean \pm SEM for $n=3$ or greater experiments.

$* P<0.05$ vs. control. 
induce arachidonate release and did not result in sarcolemmal blebbing, release of CK from the medium, or the loss of myocardial cell viability. Treatment of the myocardial cells with iodoacetate alone, DOG-OG, or DOG-CN resulted in a time-dependent release of arachidonate from membrane phospholipids, which correlated with the time course of the development of severe cell injury. In addition, there was a dosedependent relationship between the concentration of iodoacetate utilized and the release of radiolabeled arachidonate and CK into the extracellular medium. Previous studies from our laboratory have demonstrated an accumulation of free arachidonic acid in ischemic canine myocardium (13), but the relationship between the accumulation of arachidonate and the development of irreversible cell injury during in vivo myocardial ischemia was unknown (13). The current study provides a more precise temporal relationship between the release of arachidonate from membrane phospholipids and the loss of cell viability during ATP depletion.

The relationship between accumulation of radiolabeled arachidonate in the extracellular medium and the development of sarcolemmal defects suggested the possibility of a direct correlation between these two events during ATP depletion in cultured myocardial cells. There are at least two potential mechanisms by which the release of arachidonate from membrane phospholipids could be causally related to the development of sarcolemmal membrane injury during ATP depletion. First, the release of arachidonate may simply be a marker of the degradation and depletion of membrane phospholipids from the sarcolemmal membrane. It has previously been demonstrated that treatment of sarcolemmal membranes with exogenous phospholipases can result in a marked increase in their calcium permeability properties $(6,37)$. However, it should be noted that the present study does not define the intracellular membrane from which the arachidonate is released. Therefore, it is still not clear how much of the arachidonate released into the extracellular medium during ATP depletion is derived from sarcolemmal membrane phospholipids vs. phospholipids of other organellar membranes. Alternatively, the transient accumulation of arachidonate and other unesterified fatty acids in the myocardial membrane may be directly affecting myocardial membrane structure and function. Because the radiolabeled arachidonate appeared in the extracellular medium, it is clear that the arachidonate must have diffused across the sarcolemmal membrane into the extracellular space. Katz and Messineo (38) have recently demonstrated that free fatty acids can intercalate into the membrane lipid bilayer of sarcoplasmic reticulum and have marked effects on membrane calcium ATPase and permeability properties. The current study does not differentiate between any of these potential mechanisms of arachidonate release and/or arachidonate-induced membrane injury. However, the cultured myocardial cell model that has been characterized in the current study may be of use in distinguishing between these possibilities in future experiments. Interestingly, our preliminary studies have suggested that the release of $\left[{ }^{3} \mathrm{H}\right]$ arachidonate is closely correlated to an increase in $\mathrm{Ca}^{++}$uptake in cultured myocardial cells during ATP depletion (39).

In summary, the present study has demonstrated the utility of a cultured myocardial cell model in evaluating the correlation between the release of arachidonate from membrane phospholipids and the progression of cell injury and loss of cell viability during ATP depletion. In this model, the current study demonstrates that $(a)$ cultured myocardial cells display a timedependent progression of cell injury during ATP depletion; $(b)$ the morphologic pattern of sarcolemmal membrane and irreversible cell injury in the cultured cells was similar to that found in intact ischemic canine myocardial models; (c) cultured myocardial cells release arachidonate from membrane phospholipids during ATP depletion; $(c)$ in using two separate combinations of metabolic inhibitors, there was a close temporal and dose-response relationship between the release of arachidonate, the development of electron microscopic evidence of sarcolemmal defects, the release of creatine kinase into the extracellular medium, and the loss of the ability of the myocardial cells to regenerate ATP. Therefore, it is concluded that the release of arachidonate from myocardial membrane phospholipids is closely linked to the development of membrane defects and associated loss of cell viability in cultured myocardial cells during ATP depletion. If the release of arachidonate from membrane phospholipids is directly contributing to the development of irreversible myocardial cell injury, then the development and application of specific phospholipase inhibitors may be of value in protecting against these membrane alterations during cellular injury associated with marked ATP depletion. Further work will be required to define which myocardial phospholipases are releasing the arachidonic acid. In addition, this cultured cell model may prove useful in studying the biochemical link between ATP depletion and the accumulation of arachidonic acid.

\section{Acknowledgments}

This work was supported by the National Institutes of Health Ischemic Heart Disease Specialized Center of Research grant HL-17669, K08HL-01343-01, and the Harry S. Moss Heart Fund, Dallas, Texas.

\section{References}

1. Kloner, R. A., C. E. Ganote, D. A. Whalen, and R. B. Jennings. 1974. Effect of a transient period of ischemia on myocardial cells. II. Fine structure during the first few minutes of reflow. Am. J. Pathol. 74:399-415.

2. Willerson, J. T., F. Scales, A. Mukherjee, M. R. Platt, G. H. Templeton, G. C. Fink, and L. M. Buja. 1977. Abnormal myocardial fluid retention as an early manifestation of ischemic injury. Am. J. Pathol. 87:159-188.

3. Burton, K. P., H. K. Hagler, G. H. Templeton, J. T. Willerson, and L. M. Buja. 1977. Lanthanum probe studies of cellular pathophysiology induced by hypoxia in isolated cardiac muscle. J. Clin. Invest. 60:1289-1302.

4. Hearse, B. J., and S. M. Humphrey. 1975. Enzyme release during myocardial anoxia: a study of metabolic protection. J. Mol. Cell. Cardiol. 1:325-339.

5. Rude, R. E., H. S. Rubin, M. J. Stone, S. E. Lewis, R. W. Parkey, F. J. Bonte, L. M. Buja, and J. T. Willerson. 1980. Radioimmunoassay of serum creatine kinase B isoenzyme: correlation with technetium-99m stannous pyrophosphate myocardial scintigraphy in the diagnosis of acute myocardial infarction. Am. J. Med. 68:405-413.

6. Chien, K. R., J. P. Reeves, L. M. Buja, F. Bonte, R. W. Parkey, and J. T. Willerson. 1981. Phospholipid alterations in canine ischemic myocardium. Temporal and topographical correlations with Tc-99mPPi accumulation and an in vitro sarcolemmal $\mathrm{Ca}^{2+}$ permeability defect. Cir. Res. 48:711-719. 
7. Farber, J. L., K. R. Chien, and S. Mittnacht. 1981. The pathogenesis of irreversible cell injury in ischemia. Am. J. Pathol. 102: 171-178.

8. Chien, K. R., J. Abrams, A. Serroni, J. T. Martin, and J. L. Farber. 1978. Accelerated phospholipid degradation and associated membrane dysfunction in irreversible ischemic cell injury. J. Biol. Chem. 253:4809-4817.

9. Chien, K. R., J. Abrams, R. G. Pfau, and J. L. Farber. 1977. Prevention by chlorpromazine of ischemic liver cell death. Am. J. Pathol. 88:539-558.

10. Van der Vusse, G. J., T. H. M. Roeman, F. W. Prinzen, W. A. Coumans, and R. S. Reneman. 1982. Uptake and tissue content of fatty acids in dog myocardium under normoxic and ischemic conditions. Circ. Res. 50:538-546.

11. Hsueh, W., P. C. Isaksan, and P. Needleman. 1977. Hormone selective lipase activation in the isolated rabbit heart. Prostaglandins. 13:1073-1090.

12. Weglicki, W. B. 1980. Degradation of phospholipids of myocardial membranes. In Degradative Processes in Heart and Skeletal Muscle. K. Wildenthal, editor. Elsevier/North Holland, Amsterdam. 377-388.

13. Chien, K. R., A. Han, A. Sen, L. M. Buja, and J. T. Willerson. 1984. Accumulation of unesterified arachidonic acid in ischemic canine myocardium: relationship to a phosphatidylcholine deacylationreacylation cycle and the depletion of membrane phospholipids. Circ. Res. 54:313-322.

14. Prinzen, F. W., G. J. Van der Vusse, T. Arts, T. H. M. Roeman, W. A. Coumans, and R. S. Reneman. 1984. Accumulation of non-esterified fatty acids in ischemic canine myocardium. Am. J. Physiol. 247:H254-272.

15. Harary, I., and B. Farley. 1963. In vitro studies on single beating rat heart cells. Exp. Cell Res. 29:451-465.

16. Doorey, A., and W. H. Barry. 1983. The effects of inhibition of oxidative phosphorylation and glycolysis on contractility and high energy phosphate content in cultured heart cells. Circ. Res. 53:192201.

17. Bligh, E. G., and E. G. Dyer. 1959. A rapid method of total lipid extraction and purification. Can. J. Biochem. Physiol. 37:911917.

18. Pei, P. T. S., W. C. Kossa, S. Ramachandran, and R. S. Henly. 1977. High pressure reverse liquid chromatography of fatty acid Pbromophenacyl esters. Lipids. 11:814-816.

19. Halgunset, J., E. W. Lund, and A. Sunde. 1982. Improved separation of biologically relevant ${ }^{14} \mathrm{C}-{ }^{20} \mathrm{C}$ fatty acids by reverse phase high pressure liquid chromatography. J. Chromatogr. 237:496-499.

20. Anderson, F. S., and R. C. Murphy. 1976. Isocratic separation of some purine nucleotide, nucleoside, and base metabolites from biological extracts by high pressure liquid chromatography. J. Chromatogr. 121:251-262.

21. Higgins, T. J. C., D. Allsopp, and P. J. Bailey. 1980. The effect of extracellular calcium concentration and Ca-antagonist drugs on enzyme release and production by anoxic heart cell cultures. J. Mol. Cell. Cardiol. 12:909-927.

22. Lowry, O. H., N. J. Rosebrough, A. L. Farr, and R. J. Randall. 1951. Protein measurement with the Folin phenol reagent. J. Biol. Chem. 193:265-275.
23. Hayat, M. A. 1970. Principles and Techniques of Electron Microscopy: Biological Applications. Vol. 1. Van Nostrand Reinhold Co., New York. 156, 251-274.

24. Hagler, H. K., L. Sherwin, and L. M. Buja. 1979. Effect of different methods of tissue preparation on mitochondrial inclusions of ischemic and infarcted canine myocardium: transmission and analytical electron microscopic study.Lab. Invest. 40:529-544.

25. Steenbergen, C., and R. B. Jennings. 1983. Dissociation of tissue phospholipid alterations from plasma membrane injury during total in vitro ischemia in dog heart. J. Mol. Cell. Cardiol. 15:288 (Suppl. I). (Abstr.)

26. Burton, K. P., H. K. Hagler, J. T. Willerson, and L. M. Buja. 1981. Abnormal lanthanum accumulation due to ischemia in isolated myocardium: effect of chlorpromazine. Am. J. Physiol. 241:H714-723.

27. Nunnally, R. L., and P. Bottomley. 1981. Assessment of pharmacological treatment of myocardial infarction by phosphorus-31 NMR with surface coils. Science (Wash. DC). 211:177-180.

28. Chien, K. R., R. G. Pfau, and J. L. Farber. 1979. Ischemic myocardial cell injury. Am. J. Pathol. 97:505-530.

29. Chien, K. R., J. S. Crie, R. S. Decker, and K. Wildenthal. 1983. Influence of chlorpromazine on lysosomal alterations during myocardial ischemia. Cardiovasc. Res. 17:407-414.

30. Haworth, R. A., D. R. Hunter, and H. A. Berkoff. 1980. The isolation of $\mathrm{Ca}^{++}$resistant myocytes from adult rat heart. J. Mol. Cell. Cardiol. 12:715-723.

31. Morkin, E. 1971. Myocardial nucleic acid metabolism in experimentally produced hypertrophy. In Cardiac Hypertrophy. N. R. Alpert, editor. Academic Press, Inc., New York. 259-271.

32. Muntz, K. H., H. K. Hagler, H. J. Boulas, J. T. Willerson, and L. M. Buja. 1984. Redistribution of catecholamines in the ischemic zone of the dog heart. Am. J. Pathol. 114:64-78.

33. Jarmakani, J. M., T. Nagamoto, M. Nakazana, and G. A. Langer. 1978. Effect of hypoxia on myocardial high energy phosphates in the neonatal mammalian heart. Am. J. Physiol. 235:H475-481.

34. Ingwall, J. S., M. A. DeLuca, H. D. Sybers, and K. Wildenthal. 1975. Fetal mouse hearts: A model for studying myocardial ischemia. Proc. Natl. Acad. Sci. USA. 72:2809-2813.

35. Higgins, T. J. C., D. Allsopp, P. J. Bailey, and E. D. A. O'Souza. 1981. The relationship between glycolysis, fatty acid metabolism, and membrane integrity in neonatal myocytes. J. Mol. Cell. Cardiol. 13:599-615.

36. Rau, E. E., K. I. Shine, and G. A. Langer. 1977. Potassium exchange and mechanical performance in anoxic mammalian myocardium. Am. J. Physiol. 232:H85-94.

37. Langer, G. A., J. A. Frank, and K. D. Philipson. 1981. Correlation of alterations in cation exchange and sarcolemmal ultrastructure produced by neuraminidase and phospholipases in cardiac cell tissue culture. Circ. Res. 49:1289-1299.

38. Katz, A. M., and F. C. Messineo. 1981. Lipid-membrane interactions and the pathogenesis of ischemic damage in the myocardium. Circ. Res. 48:1-16.

39. Chien, K., P. Williams, J. Willerson, L. Buja. 1984. $\mathrm{Ca}^{++}$ accumulation is closely linked to the release of arachidonate from cultured myocardial cells during ATP depletion: effects of a new synthetic phospholipase inhibitor. Circulation. 70:II-78. (Abstr.) 